\title{
Genetic relationships of the Cuban hair sheep inferred from microsatellite polymorphism
}

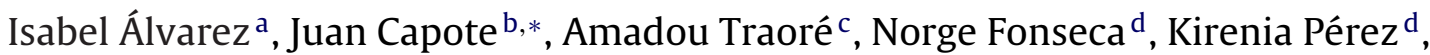 \\ Maite Cuervo ${ }^{\mathrm{a}, \mathrm{e}}$, Iván Fernández ${ }^{\mathrm{a}}$, Félix Goyache ${ }^{\mathrm{a}, * *}$ \\ a SERIDA-Deva, C/ Camino de Rioseco 1225, E-33394 Gijón Asturias, Spain \\ b Instituto Canario de Investigaciones Agrarias, E-38200 Tenerife, Spain \\ c INERA, 04 BP 8645 Ouagadougou 04, Burkina Faso \\ d Instituto de Investigaciones Agropecuarias Jorge Dimitrov, Carretera Manzanillo, km 16 1/2, Peralejo, Bayamo, Provincia Granma, Cuba \\ e SERPA S.A., C/Luis Moya Blanco 26, E-33203 Gijón, Asturias, Spain
}

\section{A R T I C L E I N F O}

\section{Article history:}

Received 5 May 2011

Received in revised form 26 October 2011

Accepted 28 October 2011

Available online 22 November 2011

\section{Keywords:}

Hair sheep

Genetic resources

Microsatellites

Genetic diversity

West Africa

Cuban Pelibuey

\begin{abstract}
A B S T R A C T
The aim of this research was to assess: (a) the genetic relationships between the Cuban Pelibuey and both the Hair-Mexican and Hair-Canarian sheep populations; and (b) the influence of African hair sheep in the formation of the Cuban Pelibuey breed. A total of 146 individuals of Cuban Pelibuey hair sheep breed were sampled and genotyped for 26 microsatellites together with 26 Hair-Mexican and 24 Hair-Canarian individuals. Additionally, the same microsatellites set was typed on 110 West African hair sheep and on 41 individuals belonging to the Wooled-Canarian (23) and the Wooled-Palmera (18) sheep breeds to be used as outgroup. Genetic distance, correspondence and STRUCTURE analyses pointed out that the Cuban Pelibuey has a particular genetic background. This population has relatively high levels of gene diversity $(0.685 \pm 0.006)$ and rarefacted allelic richness (5.9). No signals of genetic bottleneck in the Cuban Pelibuey sheep were detected. The Hair-Canarian and the Hair-Mexican populations are closely related. This is likely to be due to a major role of the Cuban Pelibuey sheep in their formation. The influence of African hair sheep into the Cuban Pelibuey could be limited and recent in historical terms.
\end{abstract}

(c) 2011 Elsevier B.V. All rights reserved.

\section{Introduction}

Hair sheep are phenotypically linked to the first sheep domestication which involved wild hair sheep in the Near East (Chessa et al., 2009). There is consensus on considering West Africa as the origin of the present-day American hair sheep (Delgado et al., 2000). However, these sheep may have been directly imported from mainland Africa into America or via the Canary Islands, a necessary stop on the

\footnotetext{
* Corresponding author.

** Corresponding author. Tel.: +34 984502010x104; fax: +34 984502012

E-mail addresses: jcapote@icia.es (J. Capote), foyache@serida.org (F. Goyache).
}

way to America (Capote and Ramírez, 1990). The original sheep stock of the Canary Islands, extinct during the late 16 th century, was hairy (Delgado et al., 2000; Tejera and Capote, 2005).

Within the Caribbean region, hair sheep breeding has a significant development in Cuba. However, no genetic analyses of the Cuban Pelibuey sheep have been carried out so far. Furthermore, the Cuban Pelibuey sheep breed has played a major role in the formation of other hair sheep populations. Mason (1980) indicates that hair sheep were brought into Mexico from Cuba during the 1930s. More recently, hair sheep were reintroduced into the Canary Islands via translocation of Cuban Pelibuey individuals obtained in Venezuela and the use of frozen semen from Cuban Pelibuey rams (Tejera and Capote, 2005). Some 
crossing with extant Wooled Canarian sheep could occur at an early moment of the formation of the Hair-Canarian population (Tejera and Capote, 2005).

Recent studies have assessed the genetic relationships and structure of some African hair sheep populations using microsatellites (Álvarez et al., 2009a; Gornas et al., 2011). The aim of this research was to assess: (a) the genetic relationships between the Cuban Pelibuey and both the Hair-Mexican and Hair-Canarian sheep populations; and (b) the influence of African hair sheep in the formation of the Cuban Pelibuey breed. Samples from wool Canarian sheep (sampled in the Tenerife and La Palma islands) were used as outgroup.

\section{Materials and methods}

\subsection{Sampling and genotyping}

Hair follicles were obtained from a total of 146 individuals of Cuban Pelibuey sheep. They were sampled in six different governmental flocks located in the municipalities of Pilón, Niquero and Media Luna belonging to the semi-arid province of Granma (Southwestern Cuba). Additionally, 26 Hair-Mexican sheep were sampled in two different flocks of the Querétaro (Central México) area and 24 Hair-Canarian individuals were obtained in two different flocks from the island of Tenerife. The relationships between the Cuban Pelibuey and the African hair sheep were assessed via the analyses of 25 Eastern Sahelian hair sheep (including Touareg, Mauritanian and Senegal samples) and the re-analysis of 95 hair sheep from Burkina Faso (including Djallonké, Mossi and Burkina-Sahel samples; Álvarez et al., 2009a). A total of 41 individuals belonging to the WooledCanarian (23) and the Wooled-Palmera (18) sheep breeds, sampled in five different flocks were used as outgroups. Information from flock managers was used to avoid the sampling of half- and full sibs.

Total DNA was isolated from hair follicles using the NucleoSpin ${ }^{\circledR}$ Tissue Kit (Macherey-Nagel GmbH \& Co. KG, Düren, Germany) according to the manufacturer instructions. A microsatellite set, including 26 markers, previously used in Álvarez et al. (2009a,b) was analysed on all the individuals (see Table S1). Genotyping was performed on an Automatic Sequencer ABI 310 using the GeneMapper software (Applied Biosystems, Barcelona, Spain).

\subsection{Statistical analyses}

The usefulness of the markers typed was assessed: (a) computing possible deviations from the Hardy-Weinberg proportions using the probability-test option implemented in the program GENEPOP v. 1.2 (Raymond and Rousset, 1995); and (b) computing the Wright's F-statistics for each marker using the program GENETIX 4.05 (Belkhir et al., 2004).

Within-populations genetic variability was assessed, using the program MolKin (Gutiérrez et al., 2005), via computing the following parameters: number of observed alleles, observed $\left(H_{\mathrm{o}}\right)$ and expected $\left(H_{\mathrm{e}}\right)$ heterozygosity, Wright's $F$-statistics and raw $(A)$ and rarefacted $\left(A_{g}\right)$ average number of alleles per locus. Here, $g$ was fitted to 30 , which is twice the minimum number of individuals within a breed with genotype known for all the microsatellites.

Detection of genetic bottlenecks in our data was tested performing a two-tails Wilcoxon test, as implemented in the program BOTTLENECK (Piry et al., 1999), under the conservative stepwise mutation model of mutation. The two-tails test ensures that statistical significance obtained using one-tail tests for heterozygote deficiency or heterozygote excess is not due to chance.

Between-populations genetic relationships were assessed, using the program MolKin, via computing the between-individuals and between-populations molecular coancestry $\left(f_{i j}\right)$ and Nei's minimum distance $\left(D_{m}\right)$ matrices. To avoid bias because of unequal sample sizes, a bootstrapping method was applied using 1000 samples with exactly 30 individuals per breed. For descriptive purposes, multidimensional scaling analysis was carried out on the genetic distance matrices using the Proc MDS of SAS/STAT ${ }^{\mathrm{TM}}$ (SAS Institute Inc., Cary, NC).

Population structure was investigated carrying out a canonical discriminant analysis, at both the population and the individual multilocus genotype levels, using the program GENETIX 4.05 (Belkhir et al., 2004). The program STRUCTURE (Pritchard et al., 2000) was also used to ascertain a possible cryptic genetic structure in the analysed dataset (Álvarez et al., 2004; Legaz et al., 2008). The most likely number of clusters $K$ (populations or breeds) present in a dataset was approached as the mode of the $\Delta K$ distribution (Evanno et al., 2005). Parameter $K$ was ascertained using 10 different runs of the program. All runs used a burn-in period of 100,000 iterations and a period of data collection of 100,000 iterations under an admixture model with correlated allele frequencies.

\section{Results}

Table S1 gives information on the polymorphism of the 26 genotyped markers. Two markers (ILSTS005 and INRA26) showed statistically significant deviations from Hardy-Weinberg proportions at the whole population level but also for most analysed populations. This scenario was not likely to be due to a chance or sampling effect. Therefore, these markers were not used for further analyses. Up to 15 out of the 24 remaining markers had more than 10 alleles and 17 markers had expected heterozygosity above 0.7. Only two of the markers (BM2504 and RBP3) showed a major heterozygote deficiency $\left(F_{I S}\right.$ values higher than 0.15). However, the standard errors associated with the estimates were wide. Therefore, these $F_{\text {IS }}$ values were not likely to result from population stratification or even problems in genotyping and, in consequence, markers BM2504 and RBP3 were kept for further analyses. Overall, the microsatellite set used was considered useful to obtain sound assessments of among-populations genetic relationships.

Parameters characterising genetic variability of the analysed sheep populations are given in Table 1 . The $F_{I S}$, $F_{\mathrm{ST}}$ and $F_{\mathrm{IT}}$ values computed at the whole population level were $0.010 \pm 0.011,0.134 \pm 0.004$, and $0.142 \pm 0.010$, respectively. At the whole population level, expected 
Table 1

Number of individuals analysed $(N)$ per country analysed population. The following parameters are given for each analysed subpopulation: observed $\left(H_{0}\right)$ and expected $\left(H_{\mathrm{e}}\right)$ heterozygosity, heterozygote deficiency within subpopulations $\left(F_{\mathrm{IS}}\right)$, raw average number of alleles per locus $(A)$ and average number of alleles per locus rarefacted to 30 copies $\left(A_{(30)}\right)$ per analysed breed and for the whole dataset. Standard deviations of the estimates are in brackets. Statistical significance of the Wilcoxon tests for bottleneck detection is also given.

\begin{tabular}{|c|c|c|c|c|c|c|c|}
\hline Population & $N$ & $H_{\mathrm{o}}$ & $H_{\mathrm{e}}$ & $F_{\mathrm{IS}}$ & $A$ & $A_{(30)}$ & $\mathrm{WT}^{\mathrm{a}}$ \\
\hline Hair-Mexican & 26 & 0.652 & $0.659(0.010)$ & $0.012(0.023)$ & 5.5 & 5.1 & n.s. \\
\hline Cuban Pelibuey & 146 & 0.675 & $0.685(0.006)$ & $0.016(0.005)$ & 7.2 & 5.9 & n.s. \\
\hline Djallonké & 31 & 0.596 & $0.645(0.008)$ & $0.075(0.005)$ & 6.2 & 5.2 & n.s. \\
\hline Mossi & 30 & 0.628 & $0.668(0.008)$ & $0.060(0.005)$ & 7.5 & 6.3 & n.s. \\
\hline Burkina-Sahel & 34 & 0.615 & $0.651(0.006)$ & $0.055(0.006)$ & 6.6 & 5.6 & n.s. \\
\hline Eastern Sahelian sheep & 25 & 0.659 & $0.639(0.006)$ & $-0.032(0.007)$ & 6.5 & 5.8 & n.s. \\
\hline Hair-Canarian & 24 & 0.661 & $0.628(0.007)$ & $-0.054(0.005)$ & 5.3 & 4.8 & n.s. \\
\hline Wooled-Palmera & 18 & 0.618 & $0.580(0.009)$ & $-0.065(0.007)$ & 4.2 & 4.1 & $*$ \\
\hline Wooled-Canarian & 23 & 0.671 & $0.677(0.006)$ & $0.009(0.005)$ & 5.8 & 5.4 & $* *$ \\
\hline Total & 357 & 0.652 & $0.748(0.003)$ & $0.010(0.010)$ & 11.0 & 6.8 & \\
\hline
\end{tabular}

a One and two asterisks mean that two-tails Wilcoxon test for heterozygote excess and heterozygote deficiency was significant, respectively, for $p<0.05$ and $p<0.01 ;$ n.s. means non-significant.

heterozygosity and rarefacted number of alleles per locus took values of $0.748 \pm 0.003$ and 6.8 , respectively.

The Cuban Pelibuey breed had the highest gene diversity $\left(H_{\mathrm{e}}=0.685 \pm 0.006\right)$ while the Mossi breed of Burkina Faso had the highest rarefacted allelic richness (6.3). Both the Cuban Pelibuey and the Eastern Sahelian sheep populations also had high allelic richness values.

The two-tails Wilcoxon test gave statistically significant signatures for population bottleneck only in the two wooled sheep populations used as an outgroup (Table 1).

The between-breeds molecular coancestry $\left(f_{i j}\right)$ and the $D_{m}$ matrices are given in Table S2. $D_{m}$ mainly characterises differentiation due to drift while molecular coancestry informs on the ancestral between-populations genetic identity (Álvarez et al., 2005). However, they gave consistent information. Considering that the between-wooled populations $D_{m}$ was $0.117 \pm 0.009$, the separation between the Cuban Pelibuey and the Hair-Canarian and HairMexican populations can be considered low $\left(D_{m}\right.$ ranging from 0.072 to 0.094 ). A similar scenario was found for the four African sheep populations, although differentiation between the Eastern Sahelian sheep and the Djallonké (West African Dwarf) tended to be higher (0.105 \pm 0.010$)$. Between-populations molecular coancestry showed a consistent pattern: the lower the differentiation, the higher the genetic identity. However, the pairs Eastern SahelianWooled-Palmera and HairCanarian-Wooled-Canarian had a relatively high molecular coancestry (higher than 0.25 ). This overall scenario is summarised in Fig. 1.

The canonical discriminant analysis identified 2 canonical variables with eigenvalue $>1$, explaining, respectively, $34.7 \%$ and $18.3 \%$ of the genetic variation contained in the dataset (Fig. 2). The pattern of dispersion obtained was similar to that provided in Fig. 1. The Hair-Mexican and Hair-Canarian populations are located together on the central part of Plot 2A and, in turn, are separated from the Cuban Pelibuey population. On the right of $X$-axis, the Eastern Sahelian sheep take an intermediate location between the Burkinabé and the American populations. Dispersion of the individual genotypes on the canonical space (Fig. 2B) gives additional information. Most Cuban, Burkinabé and wooled sheep individuals are clearly separated from the rest. However, the Hair-Mexican, the Hair-Canarian and a part of the Cuban Pelibuey individuals are intermingled. Finally, the Eastern Sahelian sheep individuals are spread between the Burkinabé and the Mexican-Canarian group.

Population structure and degree of admixture was also assessed using the program STRUCTURE. The second order rate of change of the likelihood function (Evanno et al., 2005) suggested that the most likely number of $K$ in the
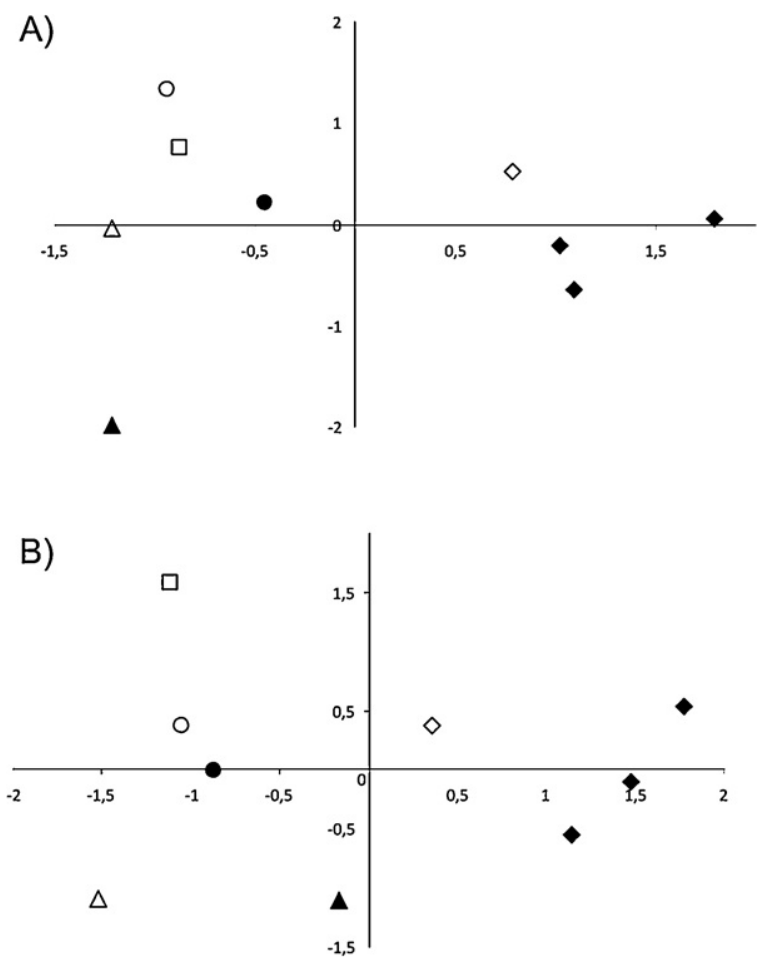

Fig. 1. Bidimensional scaling plots constructed using the betweenpopulations Nei's minimum distance matrix $\left(D_{m}\right.$; Plot $\left.\mathrm{A}\right)$ and the complementary of the between-populations molecular coancestry matrix $\left(1-f_{i j}\right.$; Plot B). Cuban Pelibuey is in open squares; Hair-Mexican sheep are in black circles and Hair-Canarian in open circles; the Djallonké, Mossi and Burkina-Sahel sheep are in black diamonds; the Eastern Sahelian population is in open diamonds; Wooled-Palmera is in black triangles and Wooled-Canarian in open triangles. The Burkinabé and the Cuban sheep are separated on Dimension 1 ( $X$-axis) while Dimension 2 ( $Y$-axis) allows differentiating the wooled subpopulations and the others. 
A)

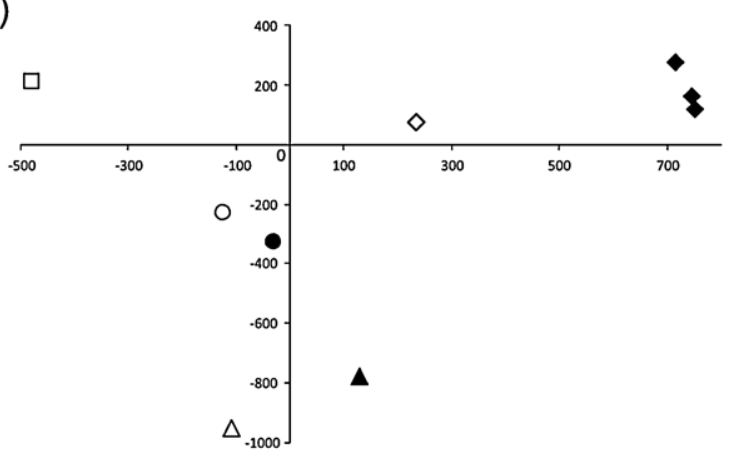

B)

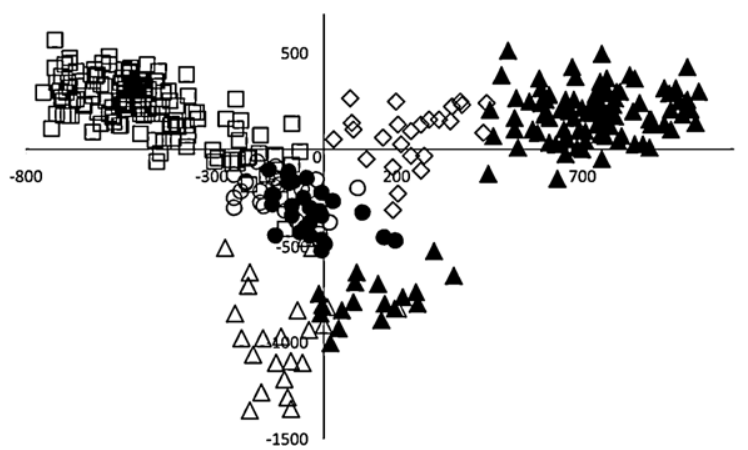

Fig. 2. Plot showing the distribution of the analysed populations (Plot A) and the individual genotypes (Plot B) on the bidimensional space formed by the two first dimensions computed by a canonical discriminant analysis. The first dimension (on the $X$-axis) explained $34.7 \%$ and the second dimension (on the $Y$-axis) explained $18.3 \%$ of the genetic variation. Cuban Pelibuey sheep are in open squares; Hair-Mexican sheep are in black circles and Hair-Canarian in open circles; the Djallonké, Mossi and Burkina-Sahel sheep are in black diamonds; the Eastern Sahelian sheep are in open diamonds; Wooled-Palmera sheep are in black triangles and Wooled-Canarian in open triangles.

dataset was 6 . Table 2 gives the membership (in percentage) of each of the analysed sheep breeds in each of the 6 most likely clusters inferred using the program STRUCTURE. Cluster 1 included most Cuban Pelibuey individuals and Cluster 5 gathered the Burkinabé breeds. The Eastern Sahelian, Wooled-Palmera and Wool Canarian individuals also formed their own clusters (6, 4 and 2, respectively). However, the Hair-Mexican, the Hair-Canarian and a significant proportion of Cuban Pelibuey individuals clustered together into Cluster 2.

\section{Discussion}

\subsection{Cuban Pelibuey sheep genetic background}

STRUCTURE and, to a lesser extent, correspondence analyses suggest that the Cuban Pelibuey has a unique genetic background. This particular genetic background does not result from population processes leading to diversity losses and increase of homozygosity. Cuban Pelibuey breed gathers a wide genetic diversity as suggested by its values of gene diversity and allelic richness. These values are comparable with those assessed for the Mossi breed (Table 1), which is an unselected-admixed population formed by continuous crossing between Sahelian and Djallonké sheep (Álvarez et al., 2009a; Traoré et al., 2008). This scenario is surprising for a population that is expected to have suffered a dramatic bottleneck during its formation, has had limited genetic contact with other hair sheep populations, at least during the last 50 years, and is under selection processes. In any case, we have not detected signals of genetic bottleneck in the Cuban Pelibuey sheep. However, this failure is not likely to be due to the inability of our microsatellite set to characterise genetic bottlenecks. These have been detected in the Wooled-Canarian and Wooled-Palmera breeds. Wooled Palmera suffered a dramatic population bottleneck during the 1970s that reduced their population sizes to roughly 50 individuals while the Wooled Canarian sheep population size decreased to a total of 30,000 individuals with a high structure among islands (Gobierno de Canarias, 1991; Álvarez et al., 2000).

\subsection{Relationships with other Caribbean sheep}

The current analyses suggest that the genetic influence of the Cuban Pelibuey sheep into the Hair-Mexican and Hair-Canarian sheep populations is strong enough to the point of allowing to consider the latter breeds as "pelibueyderived". An early intercross between the founders of the Hair-Canarian population and the extant Wooled-Canarian sheep, reflected in the closeness of the Hair-Canarian with the Wooled-Canarian individuals (Figs. 1A and 2B), has not erased the genetic relationships between the HairCanarian and the Caribbean hair sheep populations.

Table 2

Number of individuals per breed $(N)$ and proportion of membership of each of the analysed sheep breeds in each of the 6 most likely clusters inferred using the program STRUCTURE. Memberships higher than 0.1 are in bold.

\begin{tabular}{|c|c|c|c|c|c|c|c|}
\hline \multirow[t]{2}{*}{ Breeds } & \multicolumn{7}{|c|}{ Inferred clusters } \\
\hline & 1 & 2 & 3 & 4 & 5 & 6 & $N$ \\
\hline Mexico & 0.011 & 0.021 & 0.906 & 0.041 & 0.007 & 0.014 & 26 \\
\hline Hair-Canarian & 0.015 & 0.008 & 0.955 & 0.007 & 0.005 & 0.010 & 24 \\
\hline Djallonké & 0.003 & 0.033 & 0.007 & 0.006 & 0.946 & 0.005 & 31 \\
\hline Mossi & 0.007 & 0.034 & 0.012 & 0.009 & 0.923 & 0.014 & 30 \\
\hline Burkina-Sahel & 0.008 & 0.005 & 0.010 & 0.006 & 0.915 & 0.056 & 34 \\
\hline Eastern Sahelian sheep & 0.035 & 0.034 & 0.066 & 0.034 & 0.075 & 0.756 & 25 \\
\hline Cuban Pelibuey & 0.783 & 0.014 & 0.177 & 0.012 & 0.006 & 0.007 & 146 \\
\hline Wooled-Palmera & 0.004 & 0.060 & 0.006 & 0.908 & 0.008 & 0.015 & 19 \\
\hline Wooled-Canarian & 0.007 & 0.847 & 0.091 & 0.039 & 0.004 & 0.012 & 22 \\
\hline
\end{tabular}


Particularly, Fig. 2B and Table 2 suggest that a significant part of the Cuban Pelibuey individuals belong to the same genetic background as these two hair sheep populations. Although each of the flocks sampled in Cuba have particular reproduction management, they also used selected semen from Artificial Insemination centres located around La Havana. These centres could also have supplied frozen semen for foreign hair sheep populations as this happened in the Hair-Canarian population at least 15 years ago (Tejera and Capote, 2005).

\subsection{Relationships with West African sheep}

The current results suggest that the influence of African hair sheep into the Cuban Pelibuey, if existent, would be limited. Analyses carried using STRUCTURE and correspondence analyses clearly show that the Caribbean hair sheep is genetically differentiated from the African hair populations. This is so although, coastal West African individuals included in the Eastern Sahelian population tended to be genetically closer to the Hair-Mexican individuals (Fig. 2B). These genetic signatures are likely to result from processes occurring only a few generations back.

\section{Conclusions}

Here we used microsatellite polymorphism to carry out the first genetic analysis including the Cuban Pelibuey sheep together with the Hair-Mexican and Hair-Canarian breeds. Analyses included different approaches for the assessment of population structure and genetic diversity giving complementary information. Our results clearly suggest that Cuban Pelibuey sheep has a unique genetic background and that both Hair-Mexican and Hair-Canarian sheep breeds are likely to be derived from the Cuban hair sheep. Furthermore, the hypothesis suggesting that Cuban Pelibuey (and other Caribbean hair sheep) are directly derived from coastal West African hair sheep can be questioned.

\section{Acknowledgements}

This work was partially funded by grants from INIA no. RTA2006-00174-00-00 and from the Regional Government of Principado de Asturias no. IB09-114. The authors are indebted to Elvira Balguerías, Sonsoles Fernández de la Puente, Héctor Andrade, Lorenzo Hernández-Castellano, Miguel Ángel Rodríguez, Sergio Álvarez, Luis Bermejo and Ángeles Camacho for their kind collaboration in sampling.

\section{Appendix A. Supplementary data}

Supplementary data associated with this article can be found, in the online version, at doi:10.1016/j.smallrumres.2011.10.025.

\section{References}

Álvarez, S., Fresno, J., Capote, J., Delgado, J.V., Barba, C., 2000. Estudio para la caracterización de la raza ovina Palmera. Arch. Zootec. 49, 217-222.

Álvarez, I., Royo, L.J., Fernández, I., Gutiérrez, J.P., Gómez, E., Goyache, F., 2004. Genetic relationships and admixture between six Northern Spain sheep breeds assessed through microsatellites. J. Anim. Sci. 82, 2246-2252.

Álvarez, I., Gutiérrez, J.P., Royo, L.J., Fernández, I., Gómez, E., Arranz, J.J., Goyache, F., 2005. Testing the usefulness of the molecular coancestry information to assess genetic relationships in livestock using a set of Spanish sheep breeds. J. Anim. Sci. 83, 737-744.

Álvarez, I., Traoré, A., Tambourá, H.H., Kaboré, A., Royo, L.J., Fernández, I., Ouédraogo-Sanou, G., Sawadogo, L., Goyache, F., 2009a. Microsatellite analysis characterizes Burkina Faso as a genetic contact zone between Sahelian and Djallonké sheep. Anim. Biotechnol. 20, 47-57.

Álvarez, I., Gutiérrez, J.P., Royo, L.J., Fernández, I., Goyache, F., 2009b. Quantifying diversity losses due to selection for scrapie resistance in three endangered Spanish sheep breeds using microsatellite information. Prev. Vet. Med. 91, 172-178.

Belkhir, K., Borsa, P., Chikhi, L., Raufaste, N., and Bonhomme, F., 1996-2004. GENETIX 4.05, logiciel sous Windows TM pour la génétique des populations. Laboratoire Génome, Populations, Interactions, CNRS UMR 5171. Université de Montpellier II, Montpellier, France.

Capote, J., Ramírez, A., 1990. Pelibuey de Cuba: un recurso genético tropical. Centro de Información y Documentación Agropecuario, La Habana, Cuba, 20 pp.

Chessa, B., Pereira, F., Arnaud, F., Amorim, A., Goyache, F., Mainland, I., Kao, R.R., Pemberton, J.M., Beraldi, D., Stear, M., Alberti, A., Pittau, M., Banabazi, M.H., Kazwala, R., Zhang, Y.-P., Arranz, J.J., Ali, B.A., Wang, Z., Uzun, M., Dione, M., Olsaker, I., Holm, L.-E., Saarma, U., Ahmad, S., Marzanov, N., Eythorsdottir, E., Holland, M., Ajmone-Marsan, P., Bruford, M.W., Kantanen, J., Spencer, T.E., Palmarini, M.E., 2009. Revealing the history of sheep domestication using retrovirus integrations. Science 324, 532-536.

Delgado, J.V., Perezgrovas, R., Camacho, M.E., Fresno, M., Barba, C., 2000. The Wool-Less Canary Sheep and their relationship with the present breeds in America. AGRI 28, 27-34.

Evanno, G., Regnaut, S., Goudet, J., 2005. Detecting the number of clusters of individuals using the software STRUCTURE: a simulation study. Mol. Ecol. 14, 2611-2620.

Gobierno de Canarias, 1991. Consejería de Agricultura y Pesca. Estadísticas Agrarias, 12 pp.

Gornas, N., Weimann, C., El Hussien, A., Erhardt, G., 2011. Genetic characterization of local Sudanese sheep breeds using DNA markers. Small Ruminant Res. 95, 27-33.

Gutiérrez, J.P., Royo, L.J., Álvarez, I., Goyache, F., 2005. MolKin v2.0: a computer program for genetic analysis of populations using molecular coancestry information. J. Hered. 96, 718-721.

Legaz, E., Álvarez, I., Royo, L.J., Fernández, I., Gutiérrez, J.P., Goyache, F., 2008. Genetic relationships between Spanish Assaf(Assaf.E) and Spanish native dairy sheep breeds. Small Ruminant Res. 80, 39-44.

Piry, S., Luikart, G., Cornuet, J.M., 1999. Bottleneck: a computer program for detecting recent reductions in effective population size from allele frequency data. J. Hered. 90, 502-503.

Pritchard, J.K., Stephens, M., Donnelly, P., 2000. Inference of population structure using multilocus genotype data. Genet. 155, 945-959.

Mason, I.L., 1980. Prolific Tropical Sheep. Animal Production and Health Paper 17. FAO, Rome, Italy, 124 p. http://www.fao.org/DOCREP/ 004/X6517E/X6517E00.HTM.

Raymond, M., Rousset, F., 1995. GENEPOP (version 1.2): populations genetic software for exact test and ecumenicism. J. Hered. 86, 248-249.

Tejera, A., Capote, J., 2005. Colón y La Gomera. La colonización de La Isabela (República Dominicana) con animales y plantas de Canarias. Taller de Historia, Tenerife, 146 pp.

Traoré, A., Tamboura, H.H., Kabore, A., Royo, L.J., Fernández, I., Álvarez, I., Sangare, M., Bouchel, D., Poivey, J.P., Francois, D., Toguyeni, A., Sawadogo, L., Goyache, F., 2008. Multivariate characterization of morphological traits in Burkina Faso sheep. Small Ruminant Res. 80, 62-67. 